\title{
Coastal protection in Latvia
}

\author{
LIGA BRUNINA, Faculty of Economics, Latvia University of Agriculture, E-mail \\ liga.brunina@baltlineglobe.Iv \\ PETERIS RIVZA, Faculty of Information Technologies, Latvia University of Agriculture \\ POLINA SKINKE, Faculty of Geography and Earth Sciences, Latvia University
}

\begin{abstract}
This article presents the situation of existing protection solutions against the coastal erosion set up along the coast of the Baltic Sea and the Gulf of Riga in the territory of Latvia. The foreseen global climate change impacts and the ever-growing human load on the coastal areas along with the lack of erosion policy have created serious concern about safety and sustainability of the Latvian coastline. The authors argue that the lack of legislation regulating responsibilities and rights of private, legal or public land-owners in cases of coastal erosion do not facilitate the solution of problems.

To evaluate the structure of the coastal protection in terms of protected areas, types of protection solutions, number of protected areas, funding and maintenance of the protection structures, and to collect information on feedback and general knowledge about implemented coastal protection activities from the responsible institutions, interviews with the Construction Board experts were carried out.
\end{abstract}

The results show that all the experts of the Construction Boards are aware of coastal erosion issues on the Latvian coastline in general and in their competence territory in particular. Many of the experts were eager to share their opinion on coastal protection policy in Latvia and particularly the policy issues in relation to coastal erosion.

Keywords: Coastal erosion, coastal protection, climate change, integrated coastal zone management, shoreline legislation.

\section{Coastal erosion in Latvia}

Latvia is one of nine countries sharing the coastline of the Baltic Sea. It is located on the east of the Baltic Sea, and shares the sea border with another two Baltic States: Estonia to the north, and Lithuania to the south. Latvian coastline is about $500 \mathrm{~km}$ long, of which $253 \mathrm{~km}$ are the shoreline of the Gulf of Riga [Eberhards 2003]. Latvia has the second longest coastline among the three Baltic States, and within the 5-10-km-wide zone there reside 1 mill. people, which makes the Latvian coast the most densely populated coastline in the Baltics [Eberhards and Lapinskis, 2007]. 


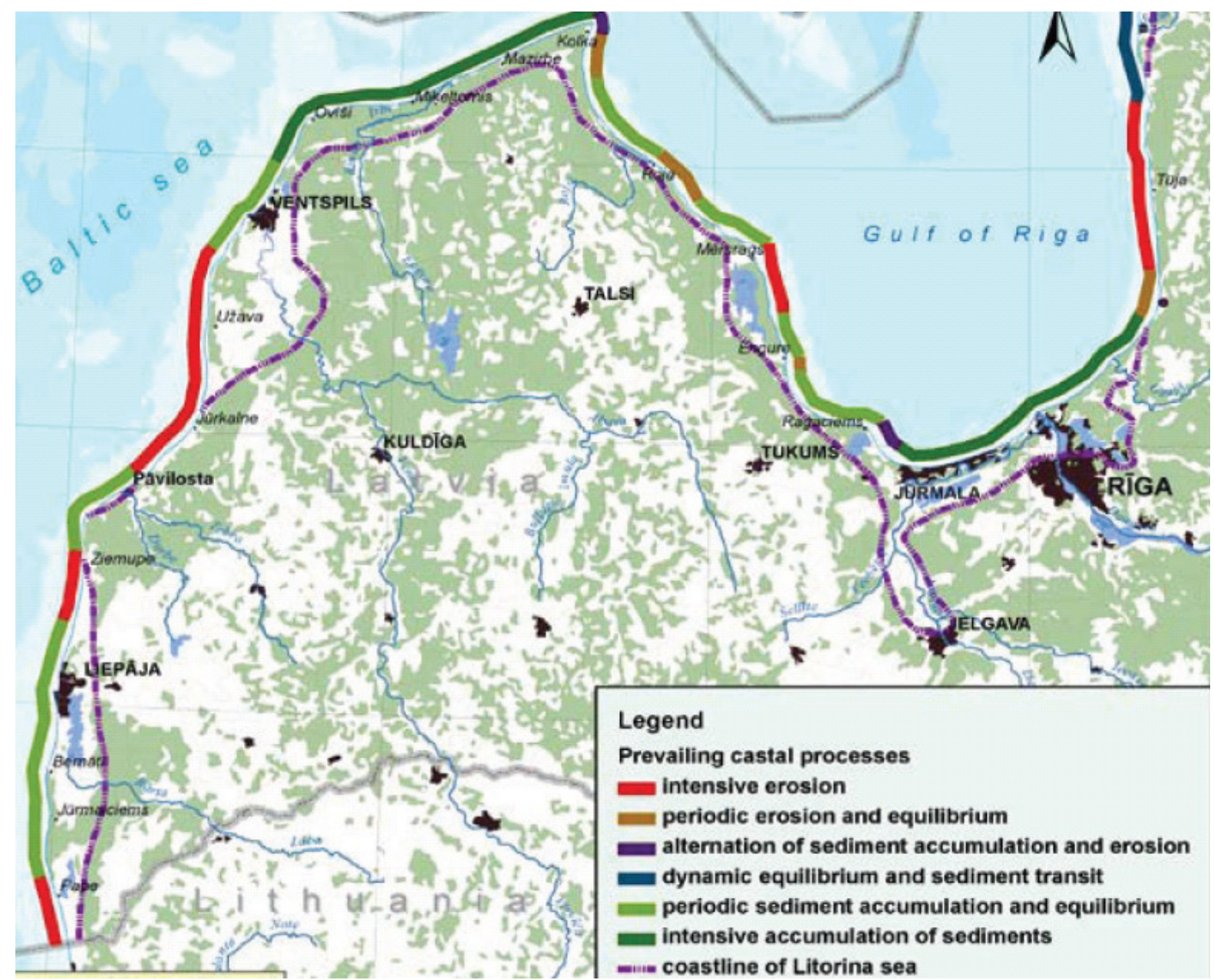

Fig. 1. Prevailing coastal processes in Latvia.

Coastal erosion has always been a typical process on the coast of Latvia. As in the other countries around the Baltic Sea and elsewhere in the world, coastal erosion in Latvia is caused by natural impacts and anthropogenic impacts, and both are expected to intensify in the following decades.

Global climate change impacts such as increasing severity and frequency of storms, rise of sea level as well as a reduction in the duration of fast ice and drift ice are seen as the most influential of natural impacts [Eberhards and Lapinskis 2007]. In addition the ever-growing demand for coastal resources like beaches, dunes, forests, biodiversity, sea waters, river deltas, and others, for industries like tourism and recreation, construction, renewable energy, ports and fishing and others are likely to intensify the human load on the coastal zones.

A number of scientific researches and national and international projects have been carried out producing data bases, high quality maps, state-of-the-art reports, national stocktaking, recommendations, guidelines, and other documents about coastal erosion in Latvia. Although recognised as an issue on a local, regional and national level, erosion is still not perceived as a loss of economically valuable property (country's, municipal, or private) by the governance bodies. Consequently there is no national policy regulating rights and responsibilities for landlords and industries in terms of prevention of coastal erosion, 
financing and setting up coastal protection structures, compensations for land loss in cases of erosion, etc.

The latest scientific research on coastal processes was carried out in 2006-2008 by Prof. G.Eberhards and the team of scientists of the Faculty of Geography and Earth Sciences of the University of Latvia. The research was part of the state research programme "KALME" on investigation how global climate change will potentially influence Latvian lakes, rivers, the Baltic Sea coast, and the coastal waters ${ }^{1}$.

The goal of the research was to show the coastal processes in the territory of Latvia over more than two thousand years. The research combined historic data, mainly morphological and geological data, to design a map of development trends on the Latvian coast during the time of formation of the Post-Litorina Sea. It includes the first coastal land survey plans at the scale of 1:2500 and 1:5000 of the first half of $20^{\text {th }}$ century, port and city plans (1900-1990), as well as the USSR Geodesic and Cartography Board's topographic maps at the scale of 1:10 000 (1980-1987), and information about coastal erosion and sediment accumulation from the research (Venska 1985-1990). More recent data from coastal monitoring stations collected in the years 1990-2007 were used for modelling Latvia's coastal processes. [Eberhards and Saltupe 1999.]. Based on this data, 27 maps were created to depict the coastal dynamics in the past 2500 years as well as to make the prognoses for the following 50 years.

The research showed that the Latvian coastline is characterised by erosion patterns, alternated with areas subject to accretion through sediment deposition. According to the data acquired from coastal monitoring stations, erosion has increased in the past 15 years compared to the $20^{\text {th }}$ century, and approximately $33 \%$ of the coastline is currently subject to erosion.

According to Eberhards (2003) and Lapinskis (2006) the most sensitive areas to erosion are from Pāvilosta to Jūrkalne, the largest capes (Mietrags, Bernāti, Melnrags), and down drift to the ports of Liepāja and Ventspils on the coast of the Baltic Sea [Eberhards et al 2009]. Ever growing and frequent storms reaching speed up to $30 \mathrm{~m} / \mathrm{s}$ and endanger $60 \%$ of the Latvian coastline. Scientists point out that approximately 160 units like private houses, nature and cultural monuments, infrastructure, cemeteries, roads etc. are threatened by erosion in the next 50 years, and another 100 units will follow.

Within the research programme "KALME" coastal areas were defined, where hard coastal defence structures, soft defence structures and no-defence zones will be applied, but the results of the programme are not considered by governmental institutions or considered in currently planning documents.

Since the present coastal population has experienced only occasional strong storms and it is only during the past 15 years that people have observed few obviously eroded coasts, the coastal protection system in Latvia is underdeveloped in terms of erosion policy, know-how, and general knowledge of coastal protection solutions. The following chapter will present an evaluation of the structure of the existing coastal protection structures along the coastline of the Baltic Sea and the Gulf of Riga in territory of Latvia.

$1 \quad$ http://kalme.daba.lv/ 


\section{Interviews with the Construction Boards}

To evaluate the structure of coastal protection in terms of protected areas, types of protection solutions, number of protected areas, funding and maintenance of the protection structures, and to collect information on feedback and general knowledge about implemented coastal protection activities from the responsible institutions, interviews with Construction Board experts were carried out.

In terms of Construction Board competences, the whole territory of Latvia is divided in eight major regions, of which two have a border with the Baltic Sea, Liepāja region and western part of Ventspils region respectively, and two are bordering the Gulf of Riga, Lielrīga region un Valmiera region respectively.

In each of the eight competence regions there are Construction Boards in each city, but the situation might differ in terms of towns, villages, and rural areas. For instance, in Liepāja region there is a Construction Board responsible for Liepāja region including territories of a number of small towns and municipalities (villages and villages with rural areas), and there is a Construction Board responsible only for Nīca municipality.

For this survey, in total 15 interviews were organised. The experts of Construction Boards of Liepāja region, Ventspils region, Lielrīga region, and Valmiera region were interviewed. Only the Construction Boards with the coastal border were included in the interviews (Fig. 2).

\begin{tabular}{|c|c|c|c|c|}
\hline \multirow{8}{*}{$\begin{array}{l}\text { T } \\
\mathbf{h} \\
\mathrm{e} \\
\mathrm{B} \\
\mathrm{al} \\
\mathrm{ti} \\
\mathrm{C} \\
\mathrm{S} \\
\mathrm{e} \\
\mathrm{a}\end{array}$} & \multicolumn{4}{|c|}{ Liepāja region } \\
\hline & Construction Board & $\begin{array}{l}\text { Coasta } \\
\text { I } \\
\text { border, } \\
\text { km }\end{array}$ & $\begin{array}{l}\text { No. of coast. } \\
\text { protect.struc } \\
t . / \\
\text { year of } \\
\text { install. }\end{array}$ & $\begin{array}{l}\text { Types of coastal protection } \\
\text { structures }\end{array}$ \\
\hline & Liepāja City & c.13 & $1 / 2005$ & SIA "Liepājas ūdens" gabions \\
\hline & Liepāja Region & 60 & $\begin{array}{l}1 / 2002 \\
1 /-\end{array}$ & $\begin{array}{l}\text { Gabions; } \\
\text { Ferro concrete blocks }\end{array}$ \\
\hline & Nīca Municipality & 22 & 0 & - \\
\hline & \multicolumn{4}{|c|}{ Ventspils region } \\
\hline & Ventspils City & 12 & $1 / 1994$ & Greenery \\
\hline & Ventspils Region & 88 & 0 & - \\
\hline \multirow{6}{*}{$\begin{array}{c}\mathbf{T} \\
\mathbf{h} \\
\mathbf{e} \\
\mathbf{G} \\
\mathrm{ul} \\
\mathbf{f} \\
\text { of } \\
\mathbf{R i} \\
\mathbf{g} \\
\mathbf{a}\end{array}$} & Roja Construction & 120 & - & $\begin{array}{l}\text { Soft constructions, mainly, } \\
\text { wickerworks; few stone stacks; } \\
\text { few large iron fortifications }\end{array}$ \\
\hline & Engure Municipality & 20 & $2 / 2009$ & $\begin{array}{l}\text { Geotextile with stones and } \\
\text { sand }\end{array}$ \\
\hline & $\begin{array}{l}\text { Lapmežciems } \\
\text { Municipality }\end{array}$ & 16 & $13 /-$ & $\begin{array}{l}10 \text { soft constructions, mainly, } \\
\text { greenery; } 3 \text { - stone stacks }\end{array}$ \\
\hline & \multicolumn{4}{|c|}{ Lielrīga region } \\
\hline & Rīga City & 15 & 0 & - \\
\hline & Jūrmala City & 32 & $2 /-$ & Soft constructions, mainly, \\
\hline
\end{tabular}




\begin{tabular}{|c|c|c|c|}
\hline & & & greenery; gabions \\
\hline Saulkrasti City & 10 & $3 /-$ & $\begin{array}{l}\text { Stone stack with rampart, } \\
\text { concrete fortification, stone and } \\
\text { wood pole based fortification }\end{array}$ \\
\hline Carnikava Municipality & 18 & 0 & - \\
\hline \multicolumn{4}{|c|}{ Valmiera region } \\
\hline $\begin{array}{l}\text { Salacgrīva and Ainaži } \\
\text { Cities with rural territories }\end{array}$ & 48 & - & $\begin{array}{l}\text { Soft constructions, mainly, } \\
\text { wicker works; stone stacks }\end{array}$ \\
\hline Liepupe Municipality & 17 & 10/1999-2009 & Stone stacks \\
\hline Skulte Municipality & 6 & 0 & - \\
\hline
\end{tabular}

Fig.2 Interviews with Construction Boards

Results show that all the experts of Construction Boards are aware of coastal erosion issues on the Latvian coastline in general and in their competence territory in particular. Many of the experts were eager to share their opinion on coastal protection policy in Latvia and the policy issues particularly in relation to coastal erosion. The general opinion was that, despite many of the protection solutions, especially the soft ones do not have a negative impact. Any of coastal protection activities must be approved by Construction Board, in order to avoid erosion, especially in cases of hard-solution construction.

Since the erosion, although being an issue, has not reached a level of serious danger yet, the number of fortified areas is comparatively small. There are in total around 34 coast protection structures on the coastline of Latvia. In terms of the types, mostly soft solutions have been applied, mainly different types of greenery, osiers, and different wickerworks in particular. However, some hard solutions have also been used, especially on the west coast of the Baltic Sea where strong storms are more frequent. Stone stacks, geotextile nets with stones and sand, concrete blocks, stone fortification walls, gabions, and iron blocks are used to fight against the water (Fig. 2).

Responsibility is unclear in the case of eroded coastal land owned by the state or the municipality. As erosion is now threatening inland private properties, especially after huge storms many of the coastal protection structures constructed privately are illegal, especially greenery, and a few hard structures constructed 10-15 years ago.

Only a few of the experts could name all the protection structures along the coast of their competence area, since no record is kept. Nor was it possible to estimate the investment made in coastal protection. The experts pointed out that the frequent shifts in employee responsibility at the Construction Boards hinder the proper data collection on the coastal protection actions, especially in terms of illegal activities and in those competence territories with a long coastline.

Despite data achieved by experts, Latvian scientists calculate approximately 400 units of coastal protection structure in 2009. It can be interpreted by the lack of regulations in the related area - as a result people who were not able to get building permits constructed coastal defence activities illegally.

In conclusion it can be argued that there are both privately funded coastal protection structures and those funded by local municipalities present along the Latvian coastline. A number of privately funded coastal protection structures made in the last 15 years can be 
seen as illegal. In two cases, the private landowner was fined. According to the interviews with the experts of Construction Boards, there is a general opinion in coastal society that the legal coastal protection costs both time and money, therefore either nothing is being done or illegal fortifications are carried out.

\section{Coastal management in Latvia}

Along with the expected changes on the Latvian coastline due to the global climate change, coastal management has become one of the top priorities. Although there is a number of laws and regulations for coastal management, Latvia does not have specific erosion-related policy, especially in terms of legislation regulating and guiding responsibilities and the rights of legal and private bodies in cases of coastal erosion.

This can be explained with the fact that erosion threat, along with the growing demand for coastal resources, has become topical only within the past 15 years, which also falls within the time line of the transition period of re-established Republic of Latvia as an independent country in 1991.

The lack of legislation and sometimes over-protection of coastal resources has resulted in a number of illegal coastal protection solutions set up along the Latvian coastline. Furthermore, since no regulations are applied in terms of the guidance and responsibilities in selection of proper protection solutions, individual construction of protection structures may end up in coastal erosion to even larger extent, especially in cases of hard solutions.

Although no erosion-laws are applicable to any activities on the coastline, there is a number of other laws and regulations that must be considered. Since joining the EU, a number of directives have been accepted and are followed by local, regional, and national government institutions, entrepreneurs and also private persons when planning, building, manufacturing, providing services, etc.

The majority of regulations are aimed at preservation of coastal resources in terms of protection of ecosystems and biodiversity. There is a number of protected nature areas located on the coastline, and, since in Latvia all the protected nature areas are also NATURA 2000 territories, all the EU directives regarding NATURA 2000 must be followed. There are several environmental laws, for instance, Environmental Protection Law and Law on Specially Protected Nature Territories, laws on individual territories under protection, i.e., Law on Slitere National Park, Law on Kemeri National Park and Law on North Vidzeme Biosphere Reserve.

The coastal policy in Latvia also sets a certain protection line or buffer zone in Protection Zone Law, which defines the types of protection zones and the functions thereof, including the Baltic Sea and the Gulf of Riga coastal protection zone; the basic principles for the establishment of protection zones; the procedures for the maintenance and control of the condition of protection zones; and restrictions of economic activity in protection zones ${ }^{2}$.

Another legislative document "Law on Environmental Impact Assessment" is perhaps the most important in terms of the prevention of coastal erosion. The purpose of this Law is to

2 http://www.likumi.lv/doc.php?id=42348\&from=off 
prevent or reduce the negative impact of the implementation of the intended activities of natural persons and legal persons or of a planning document thereof on the environment ${ }^{3}$.

Coastal policy is also inter-related to Construction Law; laws, regulations and development programmes of certain industries, for instance, tourism and ports, as well as regional level development programmes, and on local scale - municipal detailed plannings.

According to the European Commission (EC) recommendations (2002/413/EC), every European Union (EU) member country with a sea border must ensure Integrated Coastal Zone Management (ICZM). Members are free to decide how they will ensure national ICZM. Latvia has chosen to elaborate a separate document on ICZM.

The Ministry of Regional Development and Local Government (Reǵionālās attīstības un pašvaldību lietu ministrija) is currently preparing Guidelines on Sustainable Coastal Spatial Planning 2011-2017. The document is planned to be finished by the end of 2010, and it will define the priorities and goals of coastal spatial planning, value and future vision of the coast, development directions, action plans, and other aspects of ICZM.

However, despite the modern tools, like spatial planning, applied in ICZM, Latvian coastal management still has many problems, including coastal erosion cases. Of those, the majority arise due to fragmentation of landowners' structure along the coast, resulting in diverse interests. Furthermore, the Latvian state in person of the Ministry of Finance is still the owner of the beach, while the management, including recreation and tourism infrastructure and its maintenance, including beach cleaning, are financed by local municipalities.

Consequently, the above mentioned factors have been the main reasons for underdevelopment of coastal protection structures and regulations in terms of prevention of coastal erosion.

\section{Conclusions}

The coastal protection system in Latvia is underdeveloped in terms of erosion policy, knowhow, and general knowledge of coastal protection solutions. Although there are a number of laws and regulations for coastal management, Latvia does not have a specific erosionrelated policy. The lack of legislation and sometimes over-protection of coastal resources has resulted in a number of illegal coastal protection solutions.

Since no regulations are applied in terms of the guidance and responsibilities in selection of proper protection solutions, individual construction of protection structures may end up in coastal erosion to even larger extent, especially in cases of hard solutions.

Since joining the European Union (EU) in 2004, a number of EU directives as well as European Commission (EC) recommendations 2002/413/EC on Integrated Coastal Zone Management (ICZM) applies also to Latvia. While other countries in EU and elsewhere in the world have a decades-long experience with ICZM and erosion prevention, in Latvia this practise is rather new. While Latvia now is busy with the primary task to set the ICZM policy before moving to more detailed strategies for coastal erosion prevention, other countries

$3 \quad$ http://www.likumi.lv/doc.php?id=51522 
have already completed the first task, and a few have even reached the level when highly detailed policy is applied for regulation of coastal erosion prevention and defence.

Limited intervention through coastal protection zone management in accordance to Protection Zone Law, is the approach that characterises more precisely the Latvian coastal protection policy. It could be considered as priority given to the conservation of natural coastal processes, following the HELCOM Recommendation 16/3 (1995), but several important aspects are not incorporated into related governmental regulations.

The existing situation shows that experts of Construction Boards are aware of coastal erosion issues on the Latvian coastline in general and in their competence territory in particular but due to the human factor do not want to interrupt the illegally built coastal defence structures.

The main problem is that erosion is still not perceived as a loss of economically valuable property (country's, municipal, or private) by the governance bodies. It is a very serious issue which should be researched taking into consideration further activities.

\section{References}

Eberhards, G., 2003. Sea-coast of Latvia. University of Latvia, Riga, 296 pp. [In Latvian].

Eberhards, G., Grine, I., Lapinskis, J., Purgalis, I., Saltupe, B., Torklere, A. 2009. Changes in Latvia's seacoast (1935-2007). Baltica, Vol. 22 (1), 11-22. Vilnius. ISSN 0067-3064.

Eberhards, G., Grine, I., Lapinskis, J., Purgalis, I., Saltupe, B., Torklere, A. 2009. Changes in Latvia's seacoast (1935-2007). Baltica, Vol. 22 (1), 11-22. Vilnius. ISSN 0067-3064, pp.18.19.

Eberhards, G., Saltupe, B., 1999. Coastal processes monitoring in Latvia - experiment and practice. Folia Geographica VII, Geographical Society of Latvia, 1-10. [In Latvian].

Eberhards, G., Lapinskis, J., 2007. LATVIJAS JŪRAS KRASTA PROCESU ATLANTS. Valsts pētījumu programma KALME "Klimata maingas ietekme uz Latvijas ūdeņu vidi"

Eberhards, G., Saltupe, B., Lapinskis, J., 2006. Hurricane Erwin-2005 coastal erosion in Latvia. Baltica 19 (1), 10-19.

Knaps, R., 1968. In calculation of volume of alongshore sandy sediments flow within the near-shore zone. Okeanologya 8(5), Moscow, 848-857. [In Russian]. 